Timothy Brook, Jérôme Bourgon, Gregory Blue, Death by a Thousand Cuts

Cambridge (MA), Harvard UP, 2008, 230 pp.

Paul R. Katz

(2) OpenEdition

Journals

Electronic version

URL: http://journals.openedition.org/chinaperspectives/4944

DOI: $10.4000 /$ chinaperspectives.4944

ISSN: 1996-4617

Publisher

Centre d'étude français sur la Chine contemporaine

Printed version

Date of publication: 31 December 2009

ISSN: 2070-3449

Electronic reference

Paul R. Katz, "Timothy Brook, Jérôme Bourgon, Gregory Blue, Death by a Thousand Cuts », China Perspectives [Online], 2009/4 | 2009, Online since 13 January 2010, connection on 21 September 2020. URL : http://journals.openedition.org/chinaperspectives/4944 ; DOI : https://doi.org/10.4000/ chinaperspectives.4944

This text was automatically generated on 21 September 2020.

(c) All rights reserved 


\section{Timothy Brook, Jérôme Bourgon, Gregory Blue, Death by a Thousand Cuts}

Cambridge (MA), Harvard UP, 2008, 230 pp.

Paul R. Katz

1 Death by a Thousand Cuts provides a sensitive and thought-provoking treatment of one of the world's most horrific forms of penal torment, namely lingchi 凌遲, defined as the "methodical slitting and cutting apart of the condemned in a stipulated number of cuts performed in a prescribed sequence" (p. 55). The book opens with an account of one of the last known uses of this form of execution in 1904 (it was outlawed in April 1905), which involved a mass murderer named Wang Weiqin 王維勤 This is followed by a presentation of the book's two goals: 1) To trace the social and cultural history of Chinese capital punishment; and 2) To examine how such torments (and lingchi in particular) were received and reconstructed in the West. These two goals are in fact interrelated, while also being linked to the authors' overall agenda, namely to promote a "real rather than fantastical" comparative history of East and West that allows us to assess the significance of Chinese legal culture in the context of world history (p. 33).

2 The first half of the book provides a wealth of data on the history of judicial torture and capital punishment in late imperial China. Chapter 2 draws largely on materials published by legal historians to provide background information on Chinese punishments. The authors also demonstrate the importance of a suspect's confession in ensuring conviction (pp. 43,46,47), make an important distinction between torture (suffering intended to cause suspects to confess) and torment (suffering of the condemned that is intended to make an impression on onlookers) (pp. 9, 43), and emphasise the cautious attitude of imperial officials towards the taking of human life (pp. 51-52). Chapter 3 traces the origins of lingchi as a legal punishment, which may date back to the Liao dynasty but was first included in penal regulations under the Yuan (pp. 72-76, 83-84). The authors also stress elite resistance to this practice, which persisted from the Song to the Qing dynasty (pp. 77-81, 85-94). 
In Chapter 4, the authors provide a stimulating examination of the use of lingchi under Ming rule, especially following the Hu Weiyong 胡惟庸 (?-1380) affair during the reign of the first Ming emperor Taizu 太祖 (Zhu Yuanzhang 朱元璋; r. 1368-1398). Of particular significance here is the systematic analysis of the crimes for which lingchi was used as a punishment, with the authors convincingly showing that Taizu seems to have been fixated with sedition, corruption (and other "economic" crimes), and attempts to pervert the judicial system (pp. 104-116; see also pp. 55-61). There is also a stimulating discussion of the use of lingchi as a special torment reserved for rebels and other individuals who challenged state authority, and which was designed to dehumanise the culprit and restore imperial prestige (p. 71).

Chapter 5 successfully bridges the gap between legal and religious history by considering the cultural significance of the torments suffered in the underworld. The authors achieve a major analytical breakthrough by demonstrating the "distorting mimesis" of the homology between worldly legal institutions and their representations in Chinese religious tradition. Their research shows that the underworld judicial system not only reflects actual legal practice but also refashions it, with representations of the underworld imagining the power of the state without having to accurately depict it (pp. 145-149). My only quibble here involves the need to differentiate between illustrations in morality books (shanshu 善書) such as the Jade Register (Yuli 玉曆), which are devoted to exhorting people to perform good deeds, and ritual scrolls displayed during mortuary rituals, which place greater emphasis on underworld torments. Another issue meriting further research is the extent to which Western images of ghastly (and untrue) Chinese tortures may have been inspired by the aforementioned religious artworks (see in particular the illustration on p. 205, as well as the discussions on pp. 172, 177, 181, 187, 200).

5 The book's next three chapters (6-8) return to the second goal presented in its introductory chapter, namely reconsidering the historical development of Western stereotypes of Chinese punishments as inherently brutal and cruel. Here the authors convincingly demonstrate that lingchi and other forms of Chinese capital punishment were often employed as a means of emphasising innate cultural differences between East and West, or even the West's cultural superiority. At the same time, the authors also correctly point to the various forms of Orientalist exoticism, sensationalism, and sadistic sexual obsession (even voyeurism) that characterised the West's addiction to violence, including Chinese forms of torment. Chapter 6 (the longest chapter in the entire book) focuses on the works of Westerners who wrote about Chinese justice, including those who observed it firsthand. Of particular importance are the writings of nineteenth-century authors such as Régis-Évariste Huc (1813-1860) and Samuel Wells Williams (1812-1884), who stressed the stark brutality of "Oriental despotism" and the cruelty of Chinese punishments (pp. 166-174, 180-189). In Chapter 8, the authors present a devastating critique of the flawed and misleading accounts of lingchi contained in Georges Bataille (1897-1962)'s Les Larmes d'Éros (The Tears of Eros), which end up casting serious doubts on the work's authenticity (pp. 224-225, 228, 233-234).

6 In many ways, however, perhaps the most valuable of these three chapters is the shortest one, Chapter 7, which opens with a sophisticated analysis of executions as political and cultural events (p. 203). The authors then present a detailed discussion of three British accounts of Chinese executions composed between 1860 and 1910, noting that their authors stressed the Christian ideal of execution as a redemptive ordeal, 
which they then contrasted with the seemingly chaotic, casual, and passive (even apathetic) aspects of Chinese executions. This is followed by the introduction of evidence that clearly shows how these events in fact served the didactic purpose of stressing the power of the state (and edifying those who witnessed them; pp. 203-209). Particularly telling examples may be found in works such as the Xinglü tushuo 刑律圖 說(Annotated Illustrations of [Qing] Penal Law), which were published by local officials in an attempt to preserve order during the waning years of China's last dynasty (pp. 215-220). One point worth future exploration is that many of the condemned individuals portrayed in these works were women. The authors also deserve credit for their path-breaking consideration of what photographs presented in Chapter 1 reveal about Chinese witnesses to Wang Weiqin's execution, namely "a troubled fascination... an anxious and absorbed, even dejected, watching" (p. 212), which contrasts markedly with the religious themes and dramaturgical/cathartic aspects of European executions (pp. 211-213, 220). All in all, Chapter 7 serves as a model for how scholars can effectively utilise data about Chinese legal culture to overturn the erroneous representations of the past.

7 The concluding chapter (aptly entitled "Lingering On") is mainly devoted to considering the themes developed in the second half of the book, namely the ways in which lingchi became a "European cultural fetish" (p. 245). Here the authors dwell on their concern (noted in many previous reviews of this book) for critically confronting "certain older Orientalist assumptions about China [that] continue to percolate through both academic discourse and popular knowledge" (pp. 243-244). The bulk of the book's conclusion is therefore devoted to the comparison of Chinese and Western punishments, with the authors noting that "enlightened" forms of execution in the West were relatively late, and emphasising that the two systems were closer than has previously been assumed (pp. 246-250; see also pp. 9-10, 17-19, 27-28). To their credit, the authors do clearly state that identifying these Orientalist prejudices does not complete the task of enhancing our understanding of lingchi's significance in Chinese history (pp. 245-246). One issue that might be worth further consideration involves the authors' emphasis on China's "coherent, rational legal culture" (p. 69), as well as the claim that "Qing executions were secular legal events; religion did not capture them" (p. 213; emphasis added). While such assertions may be correct in terms of making comparisons to the West, there is also room for attempting a more broad-based analysis of the religious aspects of Chinese legal culture (including the altar for the executioner's swords described on pp. 65-67 and the underworld torments of Chapter 5). For example, Virgil Kit-yiu Ho's research on executions convincingly demonstrates that such acts may be viewed as sacrificial dramas portraying archetypal meanings, particularly the inevitability of retribution for those who engaged in acts of nonsanctioned violence that challenged the established political order. All this suggests that the incorporation of data from the realm of religion remains essential to our understanding of the essence of Chinese legal culture. 